See discussions, stats, and author profiles for this publication at: https://www.researchgate.net/publication/331914182

\title{
Audiovisual Industries and Tourism: Forms of Convergence
}

Chapter · April 2019

DOI: 10.1108/978-1-78769-977-920191018

\section{CITATIONS}

0

3 authors:

7. Gunnar Liestøl

University of Oslo

40 PUBLICATIONS 301 CITATIONS

SEE PROFILE

(2) Indrek Ibrus

Tallinn University

53 PUBLICATIONS 124 CITATIONS

SEE PROFILE

Some of the authors of this publication are also working on these related projects:

Cultures of Expertise View project

Project Tourism View project
15 PUBlications 2 Citations

SEE PROFILE 


\section{e emeraldinsight}

\section{Emergence of Cross-innovation Systems}

Audiovisual Industries and Tourism: Forms of Convergence

Gunnar Liestøl, Christian S. Ritter, Indrek Ibrus,

\section{Article information:}

To cite this document: Gunnar LiestøI, Christian S. Ritter, Indrek Ibrus, "Audiovisual Industries and Tourism: Forms of Convergence" In Emergence of Cross-innovation

Systems. Published online: 20 Mar 2019; 165-172.

Permanent link to this document:

https://doi.org/10.1108/978-1-78769-977-920191018

Downloaded on: 18 April 2019, At: 14:05 (PT)

References: this document contains references to 0 other documents.

The fulltext of this document has been downloaded 110 times since 2019*

\section{Users who downloaded this article also downloaded:}

,"The role of industries' environmental reputation and competitive intensity on sustainability marketing strategy: Customers' environmental concern approach",

Spanish Journal of Marketing - ESIC, Vol. 0 Iss 0 pp. - <a href="https://doi.org/10.1108/ SJME-02-2018-0005">https://doi.org/10.1108/SJME-02-2018-0005</a>

"Early supplier integration in the US defense industry", Journal of Defense Analytics and Logistics, Vol. 0 Iss 0 pp. - <a href="https://doi.org/10.1108/ JDAL-03-2018-0007">https://doi.org/10.1108/JDAL-03-2018-0007</a>

Access to this document was granted through an Emerald subscription provided by All users group

\section{For Authors}

If you would like to write for this, or any other Emerald publication, then please use our Emerald for Authors service information about how to choose which publication to write for and submission guidelines are available for all. Please visit www. emeraldinsight. com/ authors for more information.

\section{About Emerald www.emeraldinsight.com}

Emerald is a global publisher linking research and practice to the benefit of society. The company manages a portfolio of more than 290 journals and over 2, 350 books and book series volumes, as well as providing an extensive range of online products and additional customer resources and services.

Emerald is both COUNTER 4 and TRANSFER compliant. The organization is a partner of the Committee on Publication Ethics (COPE) and also works with Portico and the LOCKSS initiative for digital archive preservation.

*Related content and download information correct at time of download. 


\title{
Audiovisual Industries and Tourism: Forms of Convergence
}

\author{
Gunnar Liestøl, Christian S. Ritter and Indrek Ibrus
}

\begin{abstract}
This chapter discusses the various ways in which audiovisual (AV) media industries have cooperated with the tourism industry and explores the emergent areas for cross-innovation. It demonstrates the gradual mediatisation of tourism, but also how the added value from location tourism has started to affect, for instance, the operation of the film industry. It then discusses the emergence of tourism gamification that came about with the arrival of smartphones equipped with an ever-increasing variety of sensors relevant to location and mobility awareness. The chapter finishes by discussing the affordances and forms of augmented reality being used in the service of the cultural heritage sector and the broader tourism sector.
\end{abstract}

Keywords: Augmented reality; mixed reality; gamification; tourism; crossinnovation; audiovisual media industries

\section{Film and TV Cooperation with Tourism}

The history of audiovisual (AV) industries - more specifically film and television - cooperating with tourism is long. Tourism destinations have been advertised on TV since the earliest days of commercial television. Also, travel has been an established TV genre for decades, having historically emerged out of travel literature (Parsons, 2007), travel journalism and anthropological films (Waade, 2009). In the contemporary era, the evolving high visibility of the travel series as a genre could be linked to the growth of lifestyle programmes (Hill, 2007) that in turn could be associated with the broader evolution of the

2019, Gunnar Liestøl, Christian S. Ritter and Indrek Ibrus. Published by Emerald Publishing Limited. This chapter is published under the Creative Commons Attribution (CC BY 4.0) licence. Anyone may reproduce, distribute, translate and create derivative works of this chapter (for both commercial and non-commercial purposes), subject to full attribution to the original publication and authors. The full terms of this licence may be seen at http://creativecommons.org/licences/by/4.0/legalcode 
experience economy. The genre as it stands could be seen to combine elements from TV ads, factual entertainment genres, documentary or ethnographic films, educational programming, cooking shows, talk shows and game shows. Such hybrid formats are increasingly developed by specialised international TV channels and production companies such as Travel Channel, Discovery Channel, Pilot Production and BBC Lifestyle. This suggests also the emerging economic importance of the genre. Related to it is the realisation that the format is hybrid not only in terms of combining genre elements, but also in relation to journalistic ethics. Such programmes, especially on smaller channels, often constitute forms of native marketing, co-produced or financed by tourism agencies of various kinds. That is, the evolution of the genre has resulted from steady cooperation between the TV and tourism industries.

Yet, what needs to be realised is that in the mass media era, it was the broadcasters who had the stronger hand in this cooperation. They controlled usually both the means of production and dissemination. In terms of 'media logic', it was their logic that the tourism industries needed to accommodate. In the digital media era, with the pluralisation of channels, platforms and communities, however, the balance has shifted, and it is the tourism industry that often commissions AV content and independently disseminates it on social media, video sharing platforms or elsewhere online.

The balance has been similarly shifting in cooperation between film and tourism industries. Filming locations have been used by tourism industries for providing services for fans since before the Second World War. Yet, this strategy has only emerged as an articulated cooperation strategy between film and tourism industries in many countries during the last couple of decades. Countries, cities or regions either pay or offer tax relief to film productions that produce in their countries or, even better, explicitly place the story in these countries. When James Bond dines in a picturesque Montenegrin town, it is expected to market the tourism experience in this country. As parts of the Game of Thrones are produced in Northern Ireland, the local tourism agencies have built an extensive strategy to capitalise on this. Similarly, several cities and towns in Scandinavia are building on the prominence they have acquired through various recent TV series (Ystad, Aarhus, Lillehammer and Malmö) (Dahlström, Hedin, \& Olsen, 2010). Other countries such as the Baltic states are looking for similar opportunities as they are offering competitive cash rebates or tax relief systems for foreign productions. That is, much of the dynamics in contemporary film industries are immediately driven by the rationales and activities of the tourism industry.

\section{Forms of Gamification in the Tourism Industry}

The newest trend in cross-innovation between the screen industry and the tourism industry is the gamification of the tourism experience with the help of mobile devices. The modern history of gamification began with the loyalty programmes and sweepstakes of Sperry \& Hutchinson Green Stamps in the United States in the 1930s. Stamps were sold to retailers, such as grocery stores and gas 
stations. The retailers gave the stamps to their customers to reward them for their purchases. Such initiatives were precursors of present-day forms of gamification. The current usage of the term 'gamification' was coined by Nick Pelling in 2003. The British-born video game developer was the founder of the start-up Conundra Ltd. Gamification is the use of game-design elements in non-gaming systems to enhance the experience of users (Xu, Weber, \& Buhalis, 2014). Since millennials consume gaming as a preferred form of entertainment, managers in many industries consider gamification to be a crucial strategy for future success (e.g. Zichermann \& Cunningham, 2011). Gamification has been continuously incorporated in the domains of health care, sport, fitness and education, but not necessarily with immediate success (Gee, 2005). In the tourism industry, gamification has been a somewhat more slowly evolving trend that, perhaps notably, has roots in media - in various kinds of gamified travel and reality TV shows as described above. There has also been a growing trend in using video game scenery to promote tourism experiences in different countries (Dubois \& Gibbs, 2018).

Yet, it was the diffusion and ubiquitous use of mobile devices in everyday life that brought the possibilities for applying gamification in tourism settings to a new level. Tourism organisations emphatically invested in implementing game elements in mobile device applications. Smartphones and tablet PCs involve fastadvancing technologies, altering the parameters of consumer behaviour and business prospects in tourism (Ritter, 2017). Mobile devices are portable microtechnological systems, consisting of a microprocessor and various sensors. Global Positioning Systems (GPS), magnetometer, accelerometer and gyroscope are default hardware elements in most mobile devices. The sensor convergence on mobile platforms has turned the smartphone and tablet (as well as smart glasses) into a form of sensory and situated media. The device 'knows' where it is, in which direction it is orientated, and how it is moved. This opens up potential for communication and exchange and renders possible the invention of novel expressive forms, which dramatically alter the significance of location and place in mediated communication (Liestøl \& Morrison, 2015). The combination of mobile devices and location-tracking technologies has also prompted new understandings of space (de Souza e Silva \& Frith, 2012), and concerns regarding surveillance (Humphreys, 2013) and privacy (Gazzard, 2011; Hjorth, Pink, \& Horst, 2018).

Travel-themed applications aim to increase the motivation of visitors and deepen their engagement with tourist sites. Museums, cultural heritage sites, theme parks, architectural monuments and other tourist attractions can be experienced in new ways by eliciting information from the screens of mobile devices. This form of tourism gamification integrates the gameplay on its screen with the physical locations in tourist sites, transcending the divide between screen-framed and physical experience. Regarding such applications, notably, forms of AV content have had again a driving role - the previously mentioned forms of film tourism have been increasingly remediated and, in effect, innovated by new kinds of mobile applications. One can, for instance, discover the shooting locations of popular films using specifically designed mobile apps for orientation. Other games are about offering location-based 
transmediatic extensions, discovering specific additional elements of the stories familiar from TV or films (Ferreira, 2015).

Such applications, for the most part, build increasingly on solutions known as augmented reality (AR). The combination of mobile devices, their locationawareness and AR technologies carries great potential to enhance how tourists experience their travel destinations. Technological advancements in computing, sensor technologies and wireless communication systems paved the way for the integration of AR technology into mobile devices. Although AR has been implemented in dedicated technologies and devices since the late 1990s, for example, as head-mounted displays and mobile laptops, it was the smartphones and tablets that brought this mode of digital technology to mass audiences.

In 2016, AR had its popular breakthrough with the global attention and dissemination of the Pokémon Go game, adapted from the popular card game, TV series and console games. Pokémon Go can, in principle, be played anywhere on the globe and it is still adapted to the local topography. However, its relationship to local environments is accidental, only conditioned by the algorithmic distribution of Pokémon characters and other inventory of the game universe, all embedded in a version of Google maps with terrain information. Consequently, for the tourist, the game has little information value; wherever you travel you will discover the same critters appearing with no relationship to the local place, its history, sights and experiences. Yet, Pokémon Go is the most successful AR game and it demonstrates the two dominant modes of AR representation: mixed reality (MR) and indirect AR. MR combines a live video feed with a $3 \mathrm{D}$ graphics layer. This is an attempted implementation of the early AR visions inspired by cyberpunk literature (Gibson, 1995). Nevertheless, in actual application development it has severe deficiencies since the lack of compatibility between 2D video and dynamic 3D graphics gives rise to visual paradoxes, for example, in relationships between foreground and background. The indirect AR mode, on the other hand, avoids this problem by allocating the full screen to the constructed 3D graphics environment and then refers the mixing of real and virtual to the physical frame of the device (Kounavis, Kasimati, \& Zamani, 2012; Liestøl, 2011).

By pointing their devices in various directions, users can see an alternative digital version of the place they are in, for example, reconstructions of historical buildings at an ancient cultural heritage site where today only ruins remain. Such alternative perspectives provide digital simulations of the past, not just static buildings but animations presenting actions and events, giving enhanced user experiences of tourist sites. The device then serves as a mobile window to the past enabling individual and personalised explorations of a site's history.

Use of AR at cultural heritage sites aimed at tourism has been experimented with over the past two decades (Vlahakis et al., 2001). These forms usually demonstrate media and genre convergences between travel guides, human guiding, and location-based media. The documentary genre from film and TV also saw early adaptation in experiments with the hybrid form of 'situated documentary' (Höllerer, Feiner, \& Pavlik, 1999), which more recently has been applied to AR storytelling recounting historical events on location. Although 
such experimentations with (genre) prototypes have proved popular and promising in controlled testing (Liestøl, 2018a), it remains to be seen whether it will manage the critical leap from invention to innovation.

While cross-innovation in various media domains takes often place without explicit rational intent, invention might be achieved based on dedicated methods and techniques. As part of the Cross Motion EU Interreg project, we have experimented with genre mixing/convergence in the combinations of digitised AVarchives, AR and gamification. Our case study was the old town of Narva in Estonia that was destroyed during the final stages of the Second World War. Due to extensive photography of the old baroque town in the interwar period, it is possible to reconstruct parts of the urban structure in digital form. Our question was how may newly digitised historical photographs be combined in engaging ways with AR by means of gamification? In the Narva-project, we followed the techniques of classical rhetoric (inventio) to invent (find/discover) novel features and modes of representation, which again could be combined to form new digitally based user experiences on location (Liestøl, 2013). In this case, we explored the tradition of now-then photography or re-photography (which is closely related to the exploitation of AR in cultural heritage settings) and discovered that this practice of visual recording included many game-like features, particularly the re-photographer's urge to find the historical photo's vantage point, the place and orientation of the original photographer (Klett, 2012). Reflections on this activity of finding a position was related to analogue games sharing similar features. This methodological strategy eventually identified the Hot and Cold game and the jigsaw puzzle as relevant examples or 'blueprints' from which features could be extracted and adapted to form the gameplay elements in an AR application. In the current version of the application, the assignment to find the vantage point for six historical photos covering the old town hall square is, when successfully attained, rewarded with a dynamic AV reconstruction of everyday life on the square in the late 1930s, before the town's destruction. Testing this design solution with visitors on location proved unambiguously successful (Liestøl, 2018b). However, as Schumpeter (1939) explained, there is a fundamental difference between invention and innovation - the former does not necessarily lead to the latter, as will be demonstrated in Chapter 13 of this book. The actual success of the application depends on if the local city government, heritage institutions and tourism agencies coordinate its further development, promotion and usage (Figure 12.1).

\section{Tourism Gamification in the Global Age}

This chapter discussed the various ways in which tourism organisations have cooperated and co-innovated with AV media industries. As we learned, the most common areas of innovation are various kinds of $\mathrm{AR}$ and $\mathrm{MR}$ applications and gamification techniques. The combination of mobile devices and game thinking have fundamentally restructured the relationship between host and guest in tourist sites. The heritage industry is increasingly investing in mobile games and is open to integrating innovative solutions from the gaming industry to build on the brands, content and audience relationships cultivated by TV and film industries. 


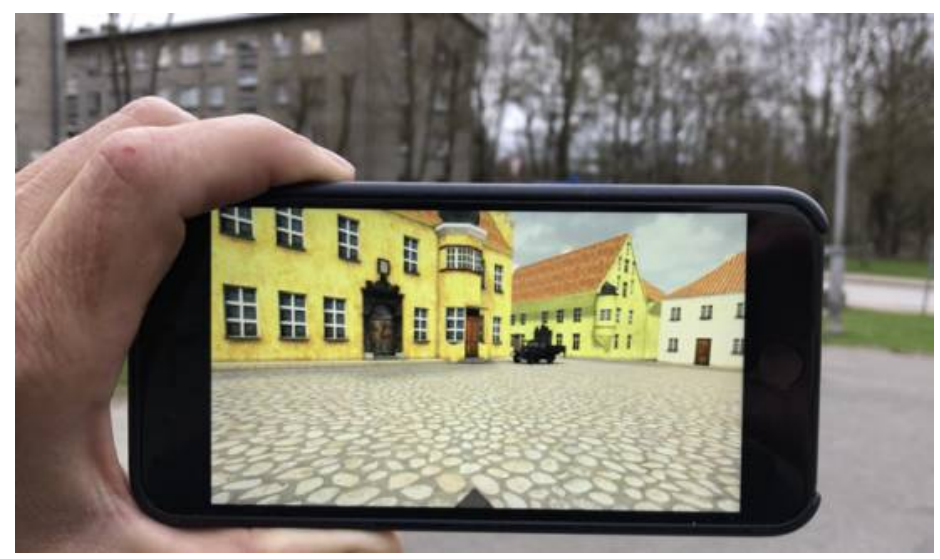

Figure 12.1. The Old Narva App in Use on Location. Note: The 'photo positioning puzzle' has just been completed and the reward of experiencing the reconstructed square as it was in the late 1930s is on display in indirect augmented reality mode.

On the one hand, the rise of travel and tourism apps has created new business opportunities for local gaming and content industries as well as for enterprises in the local tourism and cultural heritage sector. On the other hand, app stores for mobile devices have constituted global, multi-sited markets for both user data and for generic apps from global providers involving standardised maps, imagery and information on tourist attractions. As global online players are localising their services, it remains to be seen which players - global platforms or local experts - are better positioned to drive the emergent area of cross-innovation.

\section{Acknowledgement}

This work was also supported by a Mobilitas Pluss Postdoctoral Researcher Grant awarded to the second author by the Estonian Research Council (Project Number: MOBJD68). Important to signal that this chapter is also funded by Cross Motion.

\section{References}

Dahlström, M., Hedin, S., \& Olsen, L. (2010). Knowledge dynamics in moving media in Skåne - Cross-sectoral innovations in game development and film tourism. Nordregion Report 2010:1. Stockholm: Nordic Center for Spatial Development.

de Souza e Silva, A., \& Frith, J. (2012). Mobile interfaces in public spaces: Locational privacv. control, and urban sociability. New York, NY: Routledge.

Dubois, L., \& Gibbs, C. (2018). Video game-induced tourism: A new frontier for destination marketers. Tourism Review, 73(2), 186-198. doi:10.1108/TR-07-20170115 
Ferreira, S. A. M. (2015). Location based transmedia storytelling: Enhancing the tourism experience. Unpublished $\mathrm{PhD}$ thesis. University of Porto, Porto.

Gazzard, A. (2011). Location, location, location: Collecting space and place in mobile media. Convergence: The International Journal of Research into New Media, 17(4), 405-417. doi:10.1177/1354856511414344

Gee, J. P. (2005). Learning by design: Good video games as learning machines. E-Learning, 2(1), 5-16. doi:10.2304/elea.2005.2.1.5

Gibson, W. (1995). Virtual light. London: Penguin Books.

Hill, A. (2007). Restyling factual television. London: Routledge.

Hjorth, L., Pink, S., \& Horst, H. (2018). Being at home with privacy: Privacy and mundane intimacy through same-sex locative media practices. International Journal of Communication, 12, 1209-1227.

Höllerer, T., Feiner, S., \& Pavlik, J. (1999). Situated documentaries: Embedding multimedia presentations in the real world. In Proceedings of the 3rd IEEE international symposium on wearable computers (pp. 79-86). San Francisco, CA: IEEE Press.

Humphreys, L. (2013). Mobile social networks and surveillance: Users' perspectives. In A. Jansson \& M. Christensen (Eds.), Media, surveillance, and identity: A social perspective (pp. 109-126). New York, NY: Peter Lang.

Klett, M. (2012). Repeat photography in landscape research. In E. Margolis \& L. Pauwels (Eds.), The Sage handbook of visual research methods (pp. 114-131). London: Sage Publications.

Kounavis, C., Kasimati, A., \& Zamani, E. (2012). Enhancing the tourism experience through mobile augmented reality: Challenges and prospects. International Journal of Engineering Business Management, 4, 1-6. doi:10.5772/51644

Liestøl, G. (2011). Situated simulations between virtual reality and mobile augmented reality: Designing a narrative space. In B. Furht (Ed.), Handbook of augmented reality (pp. 309-319). New York, NY: Springer Science \& Business Media.

Liestøl, G. (2013). Topics of innovation. Towards a method of invention and innovation in digital media design. In T. Storsul \& A. H. Krumsvik (Eds.), Media innovations. A multidisciplinary study of change (pp. 61-74). Gothenburg: Nordicom.

Liestøl, G. (2018a). Story and storage - Narrative theory as a tool for creativity in augmented reality storytelling. Journal of Virtual Creativity, 8(1), 75-89.

Liestøl, G. (2018b). The photo positioning puzzle: Creating engaging applications for historical photographs by combining mobile augmented reality and gamification. In Proceedings of the digital cultural heritage congress 2018. San Francisco, CA: IEEE Press.

Liestøl, G., \& Morrison, A. (2015). The power of place and perspective: Sensory media and situated simulations in Urban Design. In A. de Souza e Silva \& M. Sheller (Eds.), Mobility and locative media: Mobile communication in hybrid spaces (changing mobilities) (pp. 207-222). New York, NY: Routledge.

Parsons, N. T. (2007). Worth the detour: A history of the guidebook. Stroud: Sutton Publishing.

Ritter, C. S. (2017). Travel technology. In L. L. Lowry (Ed.), The Sage international encyclopedia of travel and tourism (pp. 1332-1336). Thousand Oaks, CA: Sage Publishing.

Schumpeter, J. (1939). Business cycles: A theoretical, historical and statistical analysis of the capitalist process. New York, NY: McGraw-Hill. 
Vlahakis, V., Karigiannis, J., Tsotros, M., Gounaris, M., Almeida, L., Stricker, D., ... Ioannidis, N. (2001). Archeoguide: First results of an augmented reality, mobile computing system in cultural heritage sites. In AMC proceeding of the conference on virtual realitv. archaeologv. and cultural heritage international svmposium (VAST01). Glvfada, Greece (pp. 161-166).

Waade, A. M. (2009). Travel series as TV entertainment: Genre characteristics and touristic views on foreign countries. MedieKultur: Journal of Media and Communication Research, 25(46), 100-116. doi:10.7146/mediekultur.v25i46.505

Xu, F., Weber, J., \& Buhalis, D. (2014). Gamification in tourism. In Z. Xiang \& I. Tussyadiah (Eds.), Information and communication technologies in tourism (pp. 525-537). Vienna: Springer.

Zichermann, G., \& Cunningham, C. (2011). Gamification by design: Implementing game mechanics in web and mobile apps. Sepastopol, CA: O'Reilly Media. 